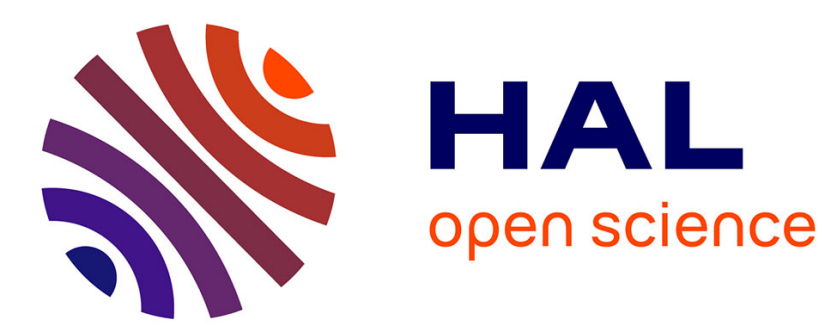

\title{
EFFECT OF STRAIN RATE ON THE TENSILE FAILURE OF GLASS-FIBRE BRAIDED TUBES
}

\author{
S. Roberts, J. Harding
}

\section{To cite this version:}

S. Roberts, J. Harding. EFFECT OF STRAIN RATE ON THE TENSILE FAILURE OF GLASSFIBRE BRAIDED TUBES. Journal de Physique IV Proceedings, 1991, 01 (C3), pp.C3-353-C3-359. 10.1051/jp4:1991351 . jpa-00250495

\section{HAL Id: jpa-00250495 https://hal.science/jpa-00250495}

Submitted on 1 Jan 1991

HAL is a multi-disciplinary open access archive for the deposit and dissemination of scientific research documents, whether they are published or not. The documents may come from teaching and research institutions in France or abroad, or from public or private research centers.
L'archive ouverte pluridisciplinaire HAL, est destinée au dépôt et à la diffusion de documents scientifiques de niveau recherche, publiés ou non, émanant des établissements d'enseignement et de recherche français ou étrangers, des laboratoires publics ou privés. 


\title{
EFFECT OF STRAIN RATE ON THE TENSILE FAILURE OF GLASS-FIBRE BRAIDED TUBES
}

\author{
S. ROBERTS and J. HARDING
}

Department of Engineering Science, University of Oxford, Parks Road, GB-Oxford OXI 3PJ, Great-Britain

\begin{abstract}
Résumé: Des essais en traction ont été réalisćs avec plus de 5 différentes vitesses de déplacement entre $1 \mathrm{~mm} / \mathrm{s}$ et plus de $20000 \mathrm{~mm} / \mathrm{s}$ sur des tubes tressés en fibre de verre avec section circulaire et carréc; les courbes force-déplacement en ont été déduites. En général on constate à la fois une augmentation de la force de traction maximale et du déplacement à la rupture, ce qui implique unc plus grande capacité d'absorption d'énergie à vitesse de déformation élcvée. Quclles que soit les vitesses de chargement, les tubes à section carréc supportent unc force maximale plus faible et la rupture se produit pour une déformation totale plus ćlevée. On considère deux étapes dans le processus de rupture, le réalignement des fibres qui s'oppose à la résistance de la matrice est suivi par la rupture en tension des fibres. Ces deux processus ont été trouvés indépendants de la vitessc.
\end{abstract}

\begin{abstract}
Tensile tests have been performed at up to five different displacement rates, from about $1 \mathrm{~mm} / \mathrm{s}$ to over $20,000 \mathrm{~mm} / \mathrm{s}$, on braided glass-fibre tubes of both square and circular cross-section and the corresponding force-displacement curves have been derived. In general both the maximum tensile force and the displacement at failure increase with increasing loading rate, implying a greater energy absorbing capability at the higher deformation rates. At all rates of loading the square cross-section tubes support a lower maximum force and fail at a higher overall deformation. Two stages in the failure process are considered, the realignment of the fibres against the resistance of the matrix followed by the tensile failure of the fibres. Both these processes are found to be rate dependent.
\end{abstract}

\section{Introduction}

Braided glass-fibre tubes have been used in the manufacture of nose cones for formula 1 racing cars and have been proposed for use in a variety of impact situations [1] including crash barriers, helicopter crash systems and protective packaging for supplies dropped by parachute. Mechanical strength in braided tubes derives from a combination of mechanical locking between the fibres due to the braided configuration, shear strength of the matrix and tensile strength of the fibres, the relative importance of each of these processes depending, in part, on the direction of the external loading.

However, although a marked strain-rate dependence of both the shear strength in polymer matrix materials [2] and the tensile strength of glass reinforcing fibres [3] has been observed a study of the overall 
effect of the rate of loading in the bralded contiguration is required before reliable estimates can be made of the efficiency of a given structural assembly of braided tubes for a particular energy absorbing application. As a first step in this direction the present investigation provides data on the effect of strain rate on the tensile properties of individual tubes of both square and circular cross-section.

\section{Specimen Material}

Braided fibre tubes in half metre lengths and of circular or square cross-section with a diameter or side length of $9 \mathrm{~mm}$ were supplied by

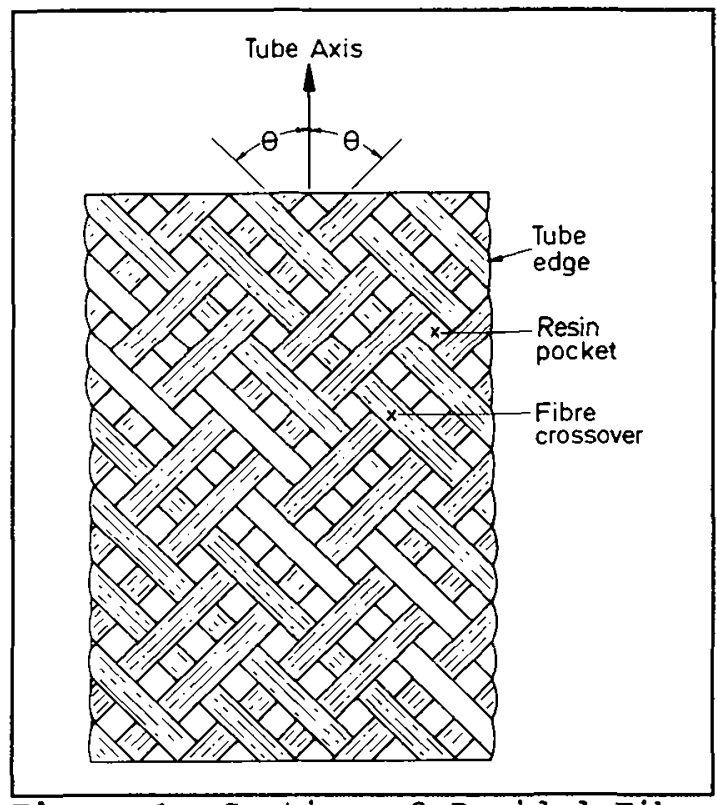

Figure 1 section of Braided Fibre Tube
Courtaulds Itd. A section of such a tube is shown in Figure 1 . In the present tests the braid angle, which may be varied for different applications, was $\sim 40^{\circ}$. The dry fibre tubes were initially impregnated with phenolic resin by pulling through a resin bath and curing over formers of the appropriate cross-section leaving a stiff but flexible tube. Mechanical strength was achieved by further impregnation with a two-part Ciba-Geigy resin, distributed by hand as evenly as possible to give a resin weight fraction after curing of about $30 \%$. Specimens of $50 \mathrm{~mm}$ overall length were carefully cut from the impregnated tubes and weighed to check the uniformity of the resin content.

\section{Testing Techniques}

Tests were performed at displacement rates of 0.95 and $8.24 \mathrm{~mm} / \mathrm{s}$ in a standard screw-driven Instron machine and 2.25 and $590 \mathrm{~mm} / \mathrm{s}$ in an open loop hydraulically-operated rapid-loading machine. In each case the specimen was fixed with epoxy adhesive between the load cell and the moving crosshead, leaving a free length of $30 \mathrm{~mm}$. The same load cell was used in both machines and the integrated output from the same pair of velocity transducers was used to determine the displacement across the specimen. A typical force $v$ displacement curve, as derived from the force $v$ time and displacement $v$ time traces for a test on a round tube at a nominal displacement rate of $590 \mathrm{~mm} / \mathrm{s}$, is shown in Figure 2 .

Tests at a displacement rate of the order of $30,000 \mathrm{~mm} / \mathrm{s}$ were performed on a tensile split- Hopkinson bar apparatus. 


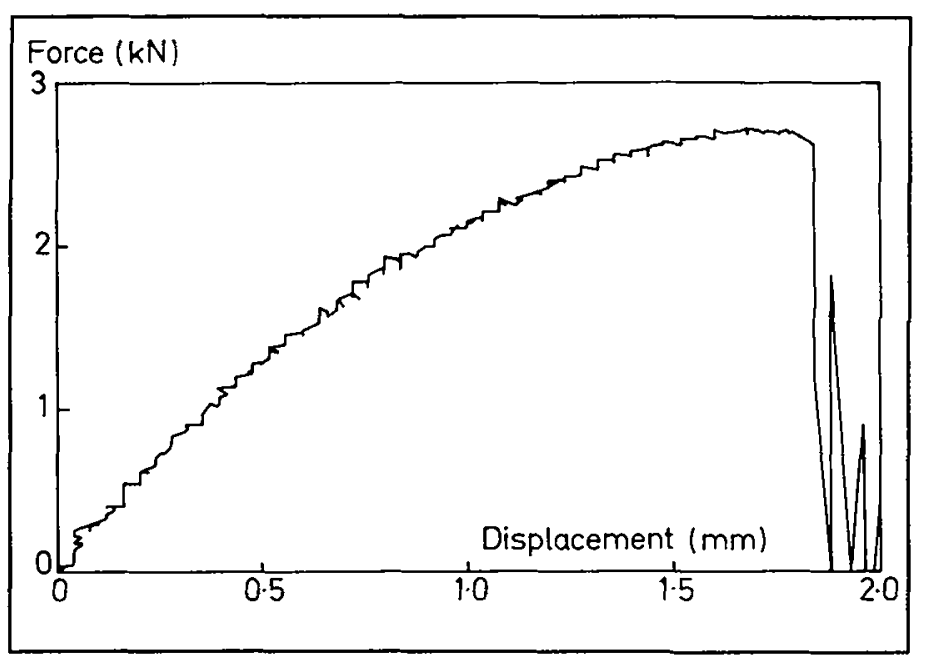

Figure 2 Force $v$ Displacement Curve for Test on Round Tube at $590 \mathrm{~mm} / \mathrm{s}$

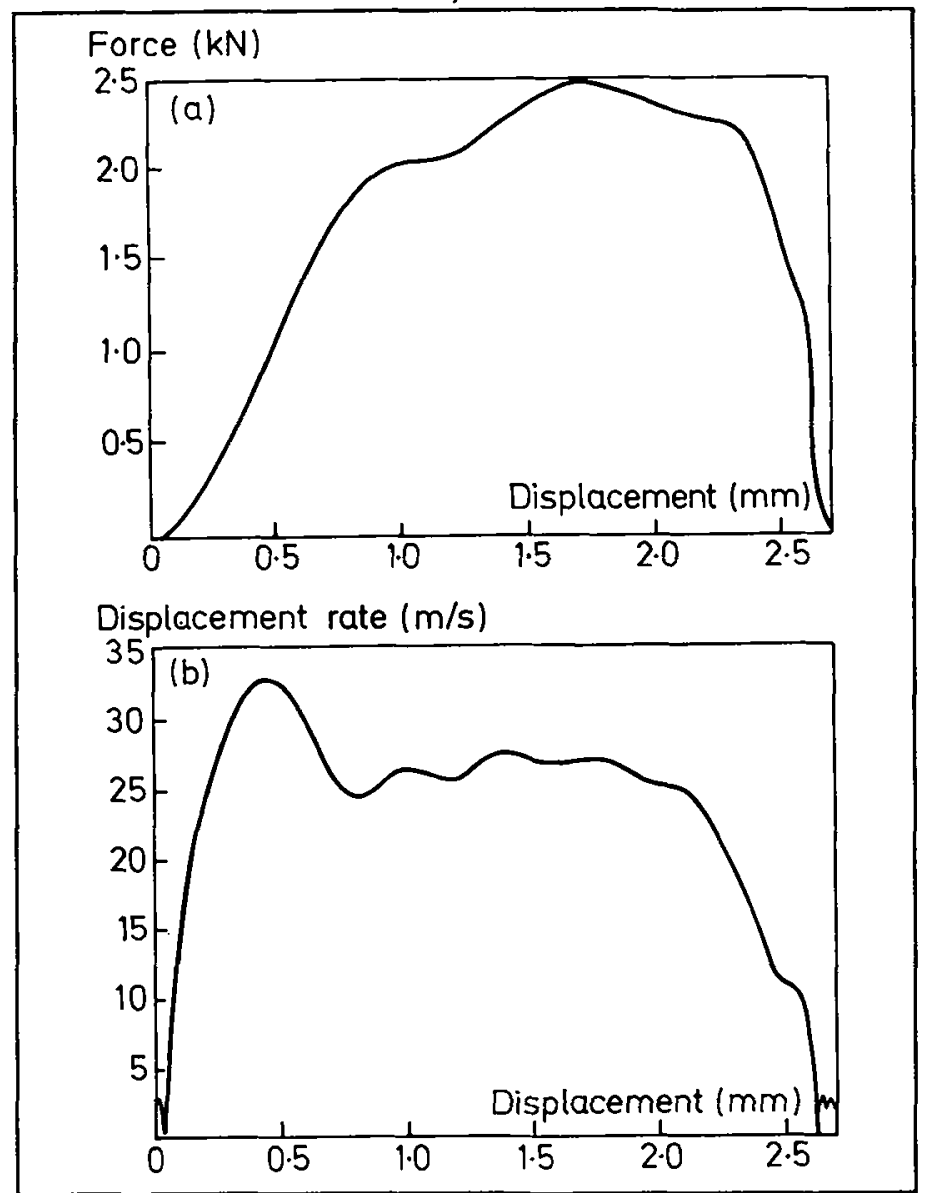

Figure 3 Impact Test on Square Tube a) Force $v$ displacement, b) Displacement rate $v$ displacement
Strain gauge signals from two stations on the input bar and one on the output bar were used to determine the force applied to the specimen and the relative displacement rate across its ends. Typical force $v$ displacement and displacement rate $\mathrm{v}$ displacement curves for an impact test on a square tube are shown in Figs. $3 a$ and $b$, respectively. Although the peak displacement rate early in the test approaches $33,000 \mathrm{~mm} / \mathrm{s}$ the mean displacement rate during most of the deformation is $-25,000 \mathrm{~mm} / \mathrm{s}$.

\section{Experimental Results}

Tubes of both round and square cross-section were loaded in the Instron testing machine at both displacement rates, in the medium rate hydraulic machine at the lower rate and in the Hopkinson-bar impact apparatus at the single rate. Only round tubes were tested at the higher rate in the hydraulic machine. The results of four tests on round tubes at the higher Instron rate and three tests on round tubes in the impact apparatus are given in Figs. $4 a$ and $b$ and show the experimental scatter to be not too great, particularly at the lower displacement rate.

The effect of the tube cross-section is shown in Fig. $5 a$ which compares mean force $v$ displacement curves for round and square tubes at the higher Instron rate. The same general trends, i.e. a higher tensile strength and a lower displacement at 
failure in the round tubes, are also seen under impact loading, as shown in Fig. $5 \mathrm{~b}$.

The effect of displacement rate on the force-displacement curves for both round and square tubes is shown in Figs. $6 a$ and $b$, respectively, where the mean results obtained at all displacement rates are compared. In general the stiffness, the maximum force and the displacement at failure all increase with displacement rate for both tube cross-sections. The force to produce a given displacement increases continuously to failure in all cases except at the highest displacement rate where a plateau or region of reverse curvature is observed before the maximum force is attained.

\section{Discussion}

As a tensile load is applied to a braided fibre tube the initial stage in the deformation process will be an attempt to reorient the fibre tows into a closer alignment with the axis of loading. This will be resisted by the resin rich regions. Since the strength of the epoxy resin is known to be strongly rate dependent [4], as long as there is structural integrity the braided fibre tubes may be expected to show an increased

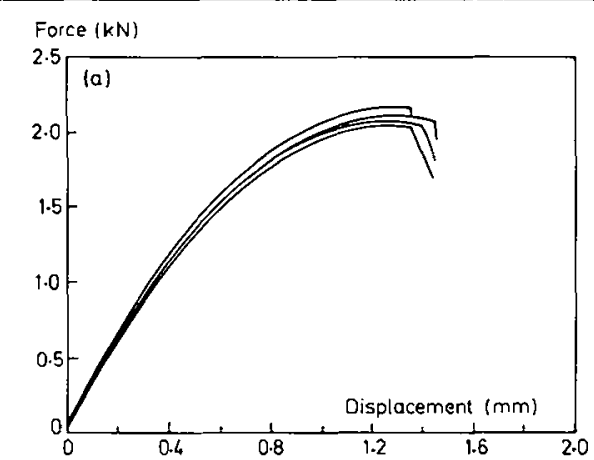

Force $(\mathrm{kN})$

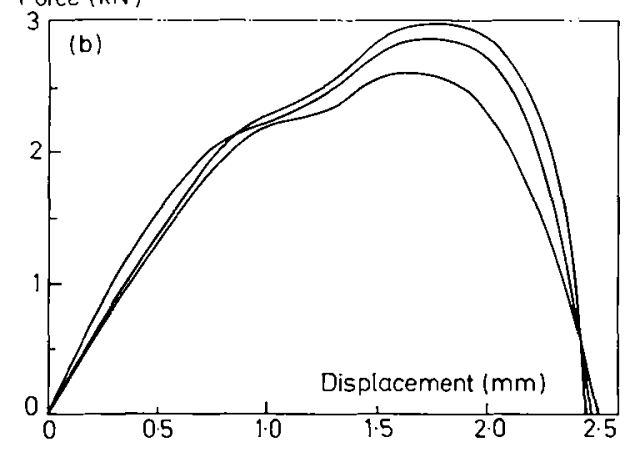

Figure 4 Comparison of Force $v$ Displacement Curves for Round Tubes at a) Low and b) High Rates

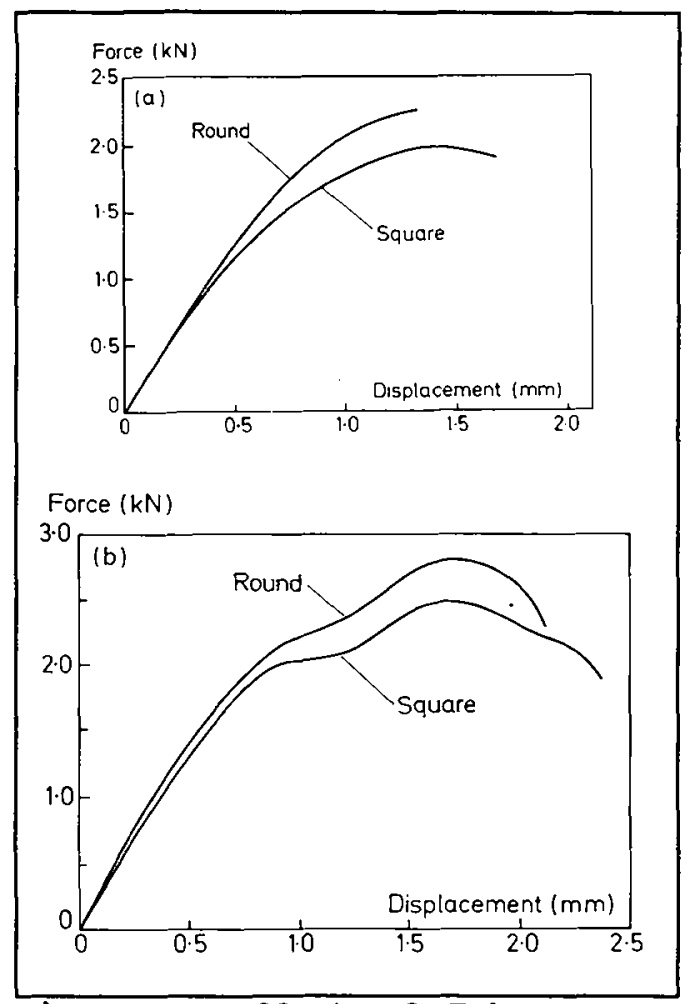

Figure 5 Effect of Tube CrossSection on Force $v$ Displacement Curves at a) $8.24 \mathrm{~mm} / \mathrm{s}$ and b) $\sim 25,000 \mathrm{~mm} / \mathrm{s}$

stiffness at higher displacement rates. Beyond a certain critical displacement however, which may or may not be rate dependent, the resin is 
11 kely to crack so that structural integrity is lost and the fibre tows can continue to realign under a reduced axial loading. Finally, as the fibre tows become more closely aligned with the direction of loading, the load they can support will increase until the fracture strength of the glass fibres is reached and overall tensile failure occurs. Since there is evidence that the fracture strength of glass fibres is also rate dependent [3] the maximum tensile force supported by the braided fibre tubes may be expected to increase with displacement rate.

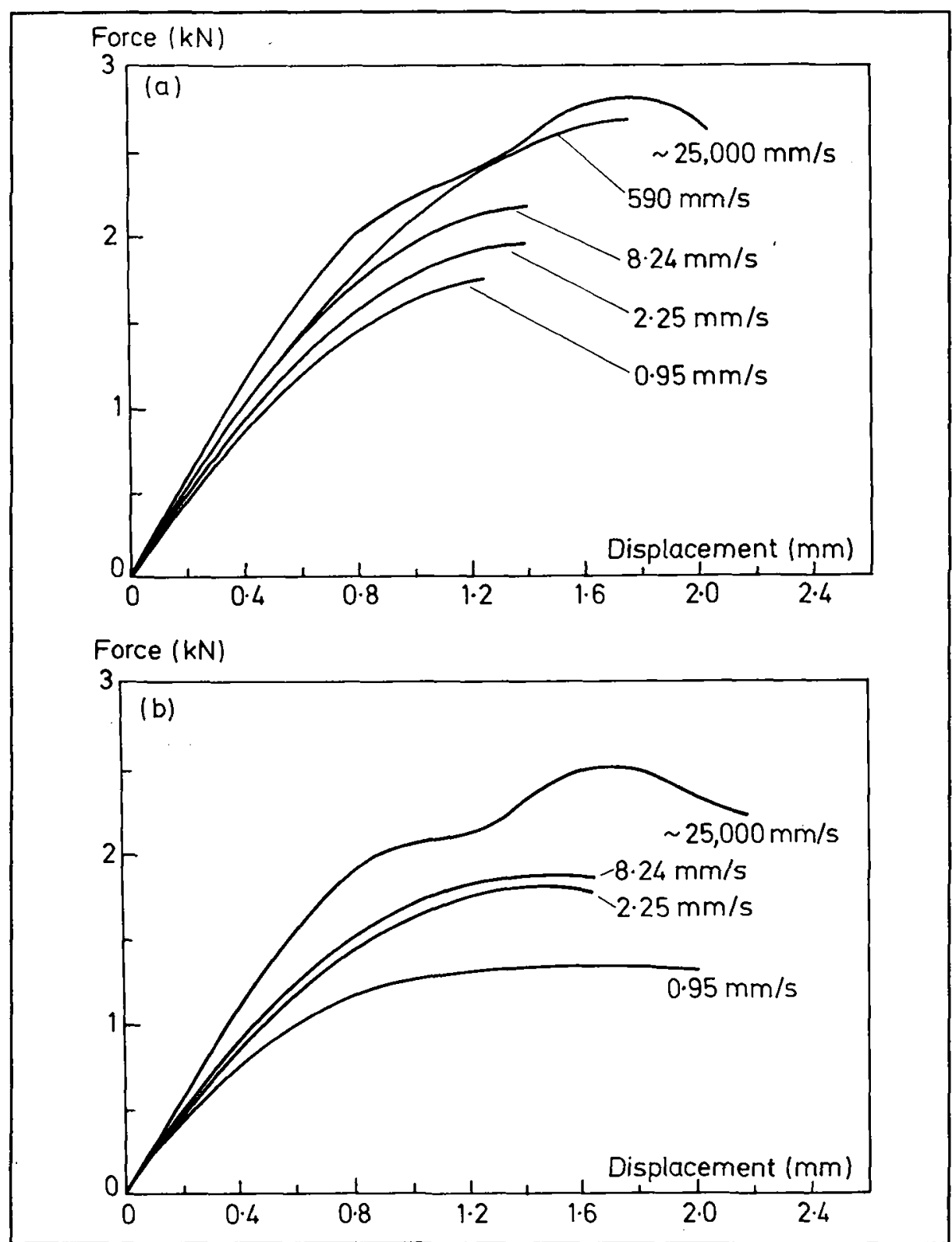

Figure 6 Effect of Displacement Rate on Force $v$ Displacement Curves for a) Round Tubes and b) Square Tubes 
A three-stage failure process of this type, i.e. initially a high stiffness followed by a reduction in load and a region of very low stiffness and then finally a rapidly increasing stiffness leading to failure, has been observed in tensile tests at both low and high displacement rates on braided fibre tubes for which the resin content was reduced to below the standard $30 \%$ level used here [5]. In the present tests, however, only at the highest displacement rate was there any indication of the second stage in this process. This implies that at the lower displacement rates the cracking of the resin increases, and hence the stiffness decreases, continuously with increasing load until the critical load is reached at which the fibres fracture. To explain the behaviour at the highest displacement rate it may be assumed that the tensile strength of the fibres increases more rapidly with displacement rate than does the load at which the resin is completely cracked.

In general the displacement at failure increases continuously with the rate of straining and is higher for the square than for the round tubes. Although it was not clear from an inspection of the broken tubes, the increase in failure displacement with rate of loading almost certainly relates to a greater length of tube over which resin cracking occurs, similar to the extended damage zone apparent in impact tests on woven fibre/epoxy composites [6]. Bearing in mind that the tubes were formed by stretching over mandrels of the appropriate cross-section the higher elongations shown by the square tubes probably relate to the observed tendency for the square section to become circular as the load increases. These various effects combine to give a significant increase in the energy absorbed, as determined from the area under the force-displacement curves of figure 6 , in fracturing single braided fibre tubes of both square and round section, see Table I, with increasing rate of loading.

\section{TABLE I Energy Absorbed in Fracturing Single Braided Fibre Tubes}

$(\mathrm{Nm})$

\begin{tabular}{cll}
\hline $\begin{array}{c}\text { Displacement } \\
\text { Rate (mm/s) }\end{array}$ & $\begin{array}{l}\text { Round } \\
\text { Tube }\end{array}$ & $\begin{array}{l}\text { Square } \\
\text { Tube }\end{array}$ \\
\hline 0.95 & 1.29 & 2.13 \\
2.25 & 1.79 & 2.04 \\
8.24 & 1.98 & 2.20 \\
590 & 3.04 & -1.0 \\
25,000 & 4.01 & 3.93 \\
\hline
\end{tabular}

\section{Conclusions}

Force-displacement curves have been obtained for braided glass-fibre tubes of both round and square section when tested in tension at displacement rates from $\sim 1$ to $\sim 30,000 \mathrm{~mm} / \mathrm{s}$. Significant increases in the strength, stiffness and displacement at failure, and hence in the energy absorbed during fracture, were observed at the higher displacement rates and may be related to the rate-dependence of the resistance of the resin matrix to fibre straightening and of the fracture strength of the glass fibres. 


\section{References}

1. M. F. A. Ajibade, J. L. M. Robinson and D. J. Williams, Energy Absorbing Structures Incorporating composite Braided Tubes, in New Generation Materials and Processes, eds. F. Saporiti, w. Merati and L. Peroni, Grafiche F.B.M., Milan, (1988), pp.307-327.

2. J. Harding, Y. L. Li and M. E. C. Taylor, "The Effect of strain Rate on the Interlaminar Shear Strength of Woven Reinforced Laminates", in Proc. ECCM-4, Developments in the Science and Technology of Composite Materials, Eds. J. Fuller et al., Elsevier Applied Science (London and New York, 1990), 517-513.

3. A. Rotem and J. M. Lifshitz, "Longitudinal Strength of Unidirectional Fibrous Composite under High Rate of Loading", in Proc. $26^{\text {th }}$ Annual Technical Conf., Reinforced Plastics/Composites Division, (Society of the Plastics Industry, New York, 1971), paper $10 \mathrm{G}$.

4. U. S . Lindholm, Some Experiments with the Split-Hopkinson Pressure Bar, J. Mech. Phys. Solids, 2, (1964), pp.317-335.

5. S. Roberts, "Effect of Strain Rate on the Tensile Failure of GlassFibre Braided Tubes", Part II Project Report, Oxford University Engineering Laboratory, June 1990.

6. J. Harding, Impact Damage in Composite Materials, Science and Engineering of Composite Materials, 1, No. 2, (1989), pp.41-68. 